\title{
12. Negotiating the sacred in law: Regulation of gifts motivated by religious faith
}

\section{Pauline Ridge}

Many people would be surprised to learn that they do not have unlimited power to give away their property as they choose. In fact, legal restrictions on gift giving operate upon gifts that take effect during the donor's lifetime (inter vivos gifts) as well as upon gifts that operate only upon the donor's death (testamentary gifts). Some of these constraints are readily comprehensible; for example, it makes sense that the law would seek to protect donors against improper exploitation by would-be donees. Other legal constraints upon gift giving, however, are more difficult to explain. Why is it, for example, the financial needs of the donor's family may take precedence over the autonomy of the donor in relation to testamentary gifts?

This paper considers legal constraints on gift giving in relation to gifts motivated by strong religious beliefs. Such gifts are not unusual. They encompass gifts to those who share the donor's religious convictions (gifts to one's faith community or a spiritual leader or mentor, for example) as well as gifts to others because of the donor's religious convictions (a gift to a charitable organisation or a will that is drawn up consistently with religious laws of succession, for example). What constraints are imposed by the law upon such gifts and, specifically, how does the law negotiate the 'sacred' in this process? The topic is an important one both for the light it may shed upon the limits of gift-giving autonomy in general, as well as for its specific relevance in a multicultural society such as Australia in which a diversity of religious faiths are practised. I have discussed such questions in more detail elsewhere; my aim in this chapter is to provide non-lawyers with an overview of the legal regulation of gifts motivated by religious faith. ${ }^{1}$

Paradoxically, these questions arise against a backdrop of purported non-intervention in religion by the law. It is often said that judges do not adjudicate upon questions of religious faith. So, for example, Gray J of the English Queens Bench recently refused to allow a defamation action to proceed as it would require him to decide a matter of doctrinal dispute (whether the claimant was a validly consecrated bishop or not). ${ }^{2}$ Similarly, Australian courts have refused to adjudicate on the doctrinal disputes concerning ordination of women within the Anglican Church. ${ }^{3}$ Although sometimes explained as due to the complexity of religious doctrine, in fact the refusal is public policy based: courts should not engage in a qualitative assessment of religious doctrine. ${ }^{4}$ 
Murphy J, of the High Court of Australia, in deciding whether or not the Church of Scientology constituted a 'religion' for taxation exemption purposes explained it thus:

Religious discrimination by officials or by courts is unacceptable in a free society. The truth or falsity of religions is not the business of officials or the courts. If each purported religion had to show that its doctrines were true, then all might fail. ${ }^{5}$

The courts will only decide disputes occurring in a religious context if they raise legal questions not dependent upon a qualitative assessment of religious doctrine. Thus, property disputes arising out of church schism can be determined because the court simply applies the principles of property law. ${ }^{6}$ The courts will even decide whether a set of beliefs and practices of a group constitutes a religion. ${ }^{7}$ In doing so the court does not make a qualitative assessment of the purported religion except to the extent that parody or sham religions are not accepted. ${ }^{8}$

How, then, does this 'hands off' approach to matters of religious belief translate to the legal regulation of gift giving? Presumably legal regulation of gifts motivated by religious beliefs is possible because the motivations are seen as peripheral to the legal issue of the validity of the gift. The courts are not asked to directly evaluate the donor's motivations and the legal principles that apply to religiously motivated gifts are the same as those that apply to all gifts. What is interesting is that in fact, the law does confront the religious faith of the donor ('the sacred') and pass judgment upon it in regulating gifts motivated by religious faith. This is done both directly - through protection from exploitation of religious belief and by prioritising other demands upon the donor's property - and indirectly, through the use of objective standards in the relevant legal doctrines.

Before considering these points in detail, it may be helpful to briefly describe the relevant law. Inter vivos gifts and testamentary gifts are largely regulated by separate bodies of judge-made law. The doctrines that regulate inter vivos gifts come mainly from Equity (the body of law initially developed by the Court of Chancery in England). The two equitable doctrines most relevant to gifts motivated by strong religious faith are equitable undue influence and unconscionable dealings. Testamentary gifts fall into the law of succession (a mixture of probate law, Equity and legislation). The most relevant doctrines are probate undue influence and the suspicious circumstances doctrine.

It is also possible to create a trust of the donor's property for the benefit of whatever person (or, possibly, purposes) the donor chooses rather than make an outright gift of the property. The principles of trust law (which are also part of Equity) operate equally upon inter vivos and testamentary gifts. Finally, gift giving is also subject to legislative regulation. The legislation most pertinent to 
this discussion is family provision legislation which exists under different names in all Australian jurisdictions and only applies to testamentary gifts. ${ }^{9}$

Whichever source of law is used to regulate gift giving, the gift must be a significant one relative to the donor's overall assets. For pragmatic reasons a gift will not be disputed in the courts (a costly process) unless it is sufficiently large to cause pain/outrage to the person(s) who otherwise expected to benefit; and legally, the relevant doctrines tend not to be activated by small gifts. With this background in mind then, how does the law negotiate the sacred in its regulation of gifts motivated by strong religious beliefs?

\section{Direct consideration of the donor's religious motivations}

\section{Protection from exploitation}

The first way in which the law directly confronts the religious motivations of a donor is by protecting donors from exploitation of those motivations. The legal doctrine most relevant to inter vivos gifts in this context is equitable undue influence. Equitable undue influence is concerned with gifts arising out of a relationship of influence or potential influence. The doctrine developed in the late eighteenth century and some of the leading cases concern religiously motivated gifts. A presumption that 'undue' influence has been exercised over the donor arises upon evidence that:

- a gift was made to a donor's spiritual 'leader'; and,

- the gift is 'so large as not to be reasonably accounted for on the ground of friendship, relationship, charity, or other ordinary motives on which ordinary men act... 10

Alternatively, in place of the first requirement, a relationship of influence can be proved by evidence of the particular relationship, in which case the presumption is similarly activated once the second requirement is also proved. Once a presumption of undue influence arises (either automatically or because a relationship of influence is proved) then the gift is overturned unless the donee rebuts the presumption by evidence that no advantage was taken of the donor who in fact exercised a fully informed, free and independent judgment. ${ }^{11}$ Whether the donor received independent advice regarding the gift is relevant to rebuttal of the presumption.

There is strong rhetoric in the equitable undue influence cases concerning the danger of spiritual influence. Spiritual influence was said to be the most dangerous and the most powerful' of all influences upon a donor or a party to a contract. $^{12}$ The following statement by counsel arguing a case at the beginning of the nineteenth century, whilst no doubt calculated to sway the court, nonetheless encapsulates the concerns of lawyers at the time: 
What is the authority of a guardian, or even parental authority, what are the means of influence by severity or indulgence in such a relation, compared with the power of religious impressions under the ascendancy of a spiritual adviser; with such an engine to work upon the passions; to excite superstitious fears of pious hopes; to inspire, as the object may be best promoted, despair or confidence; to alarm the conscience by the horrors of eternal misery, or support the drooping spirits by unfolding the prospect of eternal happiness: that good or evil, which is never to end? What are all other means to these? ${ }^{13}$

Unsurprisingly, there is a string of English cases throughout the nineteenth and early twentieth centuries in which gifts motivated by strong religious beliefs, and generally involving fringe religious groups, were set aside. ${ }^{14}$

Importantly, equitable undue influence affects not only gifts that are the product of clear and deliberate exploitation of influence but also gifts where there is only the possibility of exploitation and where all parties have acted in good faith. The leading case of Allcard $v$ Skinner, decided in 1887, illustrates this point. A novice Anglican nun (Miss Allcard) gave all her assets to the Head of her Order (her mother superior) as required by the rules of the Order. The property was used for charitable purposes of the Order. The English Court of Appeal stressed that all parties had acted with complete propriety; nonetheless the presumption of undue influence that arose automatically due to the relationship of Miss Allcard and her mother superior was not rebutted. Crucially, Miss Allcard had not received independent advice before making the gifts and could not be shown to have exercised a fully informed and free judgment, free of the influence of her mother superior. Thus, the doctrine is concerned with the potential for undue influence to be exercised and will err on the side of caution; gifts will be set aside if it cannot be conclusively proved that the donor acted free from undue influence.

Equitable undue influence continues to be applied today across a spectrum of religious faiths. ${ }^{15}$ There have been five reported Australian cases since 1986 (all involving female donors). The donees have included a Baptist pastor, the leaders of a Hare Krishna community and the leader of a breakaway sect from the Church Universal and Triumphant. ${ }^{16}$ It is not necessary that the donee be formally recognised as a spiritual 'leader'; a recent Queensland case acknowledged the possibility of a bible study group leader being in a position of spiritual influence. $^{17}$

I will return to the second requirement of equitable undue influence (that the gift is 'so large as not to be reasonably accounted for on the ground of friendship, relationship, charity, or other ordinary motives on which ordinary men act') below; however, it is also worth noting that this requirement limits the doctrine's utility regarding 'repeat offenders'. In other words, it is possible that a spiritual 
leader or mentor may abuse his or her position of influence with respect to many donors but in relation to relatively small gifts which do not activate the presumption. Equitable undue influence is concerned not so much with the regulation of spiritual leaders/mentors as such, as with undoing particular gifts; thus there is still the need for vigilance and appropriate self-regulation by religious groups. Codes of conduct for Christian churches are growing in popularity (partly because of a growing awareness of sexual abuse within churches) and these may include provisions regarding receipt of financial benefits. $^{18}$

The related equitable doctrine of unconscionable dealings also may apply to inter vivos gifts motivated by strong religious beliefs. While equitable undue influence considers the relationship between donor and donee, unconscionable dealings looks more to the circumstances of the particular gift. If a donor suffers from a 'special disadvantage' relative to a donee, and if the donee knows or ought to know of that disadvantage it may be unconscionable for the donee to accept the gift. 'Special disadvantage' traditionally included conditions such as drunkenness, ill health, lack of education and poverty. The court considers whether there is a special disadvantage by comparing the relative abilities and conditions of the two parties to the gift. Strong religious faith-especially in the first flush of a religious conversion - may be characterised as a 'special disadvantage'; that is, a person of strong religious convictions may be considered so vulnerable to exploitation that it is unconscionable for the donee to accept the gift knowing these facts. In this instance, the implication is that although the donor acted with autonomy the donee should not have benefited from their spiritual fervour without ensuring that they received independent advice. There are no decided cases in which unconscionable dealings has been applied to religious enthusiasm; however, this can be explained by the fact that the doctrine is not often applied by the English courts and is relatively recent in its Australian usage.

Interestingly, the law is not so concerned with the danger of exploitation of religious faith in relation to testamentary gifts. Two doctrines that protect against exploitation in relation to testamentary gifts motivated by strong religious faith are probate undue influence and the suspicious circumstances doctrine. Unlike equitable undue influence which is concerned with the potential for abuse of influence, probate undue influence requires proof that the donor was actually coerced into making a gift that did not represent their intention and desire at all. ${ }^{19}$ Thus, in a case where the residuary beneficiary of a will (a Roman Catholic priest) was chaplain and confessor to the testator, a challenge to the gift on the basis of probate undue influence failed because there was no evidence of coercion:

No amount of persuasion or advice, whether founded on feelings of regard or religious sentiment, would avail, according to the existing law, 
to set aside this will, so long as the free volition of the testatrix to accept or reject that advice was not invaded. ${ }^{20}$

Because of this the doctrine of probate undue influence is notoriously difficult to establish.

The suspicious circumstances doctrine may be more helpful in overturning a testamentary gift motivated by religious faith. One requirement for a valid will is that the testator knew and approved of the will's contents. If there are suspicious circumstances surrounding the making of the will, then the propounder of the will must prove knowledge and approval affirmatively. There is no limit on what may constitute a suspicious circumstance; one example is where the sole or major beneficiary assisted in the preparation of the will. ${ }^{21}$ So, for example, in In the Will of Thomas Walsh the testator's priest drew up the will in the testator's last days and while he was seriously ill. ${ }^{22}$ The whole of the estate went to projects associated with the priest. A'Beckett $J$ found that the circumstances surrounding preparation and execution of the will cast doubt on the testator's knowledge and approval of the will's contents and he therefore refused probate.

Why is the law concerned about exploitation of religious faith in relation to inter vivos gifts but not to the same extent in relation to testamentary gifts? Elsewhere I have suggested that it is because the donor of a testamentary gift is, by definition, not impoverished by the gift and thus, there is no immediate and direct 'victim' of the gift: but that this is unsatisfactory because those who otherwise would benefit from the donor's bounty are also affected. ${ }^{23}$ More cogent reasons are that the succession doctrines developed during the mid to late nineteenth century when quite blatant lobbying of testators was socially acceptable, the difficulty of proving the circumstances of a will long after it was made and when the disaffected parties may not even have been present, and the different jurisdictional origins of the applicable law. It may be that equitable undue influence (which at present does not apply to testamentary gifts) will influence the development of the law of succession in the future.

\section{Priority given to competing values}

A second way in which the law directly confronts the sacred when regulating gifts occurs when other values are given priority over the autonomous expression of the donor's religious faith. The clearest example of this is in relation to testamentary gifts where the law recognises a societal norm that the financial needs of one's dependents must be catered for before one acts benevolently towards others. A distinction is drawn between a right of inheritance by the donor's family (which is not recognised) and a right to provision for financial needs (which is recognised). Two cases illustrate the point. The first case, The Trustees of Church Property of the Diocese of Newcastle $v$ Ebbeck, is authority that 
a donor may impose religiously motivated conditions upon a gift. That is, no one, other than the testator (and, presumably, the testator's creditors) has any right to the testator's property. In the words of Windeyer J of the High Court of Australia:

[A testator] may, if he wishes, provide that his property shall go only to persons of a particular religion. He may stipulate that a prospective beneficiary will be disqualified unless he renounce a particular faith...Furthermore, a testator may disqualify from participation as a beneficiary anyone who should marry a spouse of a particular religion, or not marry a spouse of a particular religion. ${ }^{24}$

This is a strong endorsement of the autonomy of a religiously motivated donor and confirms my comments in the introduction regarding the hands-off approach of law to religious faith; however, the second case, Wenn $v$ Howard, shows that such autonomy must give way to the financial needs of a testator's dependents. ${ }^{25}$ In that case a testator deliberately excluded some of his children from his will because (it was said) they did not practise the Catholic faith. It was held by the court that this would not disentitle them to provision from the estate if financial need was established; in other words, there was no right to inheritance but there was a right to family provision and the latter overrode the autonomy of the religiously motivated testator.

Although the details of family provision legislation (also known as 'testator's family maintenance') vary between jurisdictions, such legislation generally provides that testamentary gifts (and even gifts made shortly before the donor's death) can be overridden to the extent that the financial needs of the donor's immediate family and dependents have not been provided for. The Court may order that provision be made out of the deceased donor's estate for the 'maintenance, education or advancement in life' of a family member or dependent. $^{26}$ To the extent that religiously motivated gifts may be overridden by court ordered family provision the law is prioritising the financial needs of the donor's family over the autonomous expression of the donor's religious faith. In some jurisdictions the court has power to determine which gifts under the will should bear the burden of a family provision order and this may further disadvantage religiously motivated gifts.

Protection from exploitation and legislative acknowledgement of the right of family members to financial provision from a deceased donor's estate are two ways in which the legal regulation of gifts directly confronts the donor's religious faith; but there are more subtle ways in which the law negotiates the sacred and this is by use of objective standards. 


\section{Indirect consideration of the donor's religious faith through the application of objective standards}

The legal regulation of gift giving is premised upon objective standards of behaviour that encapsulate societal norms. In the second part of this chapter I will suggest that the law negotiates the sacred in an indirect and possibly discriminatory way through the application of objective standards. Donors motivated by strong religious faith are likely to fall outside societal norms embedded in the relevant legal doctrines and are disadvantaged by an unthinking application of such norms in the law. This happens in two ways. First, donors of strong religious faith are less likely to meet objective standards based upon societal norms. Secondly, the content of such standards, whilst appearing neutral, may reflect the dominant religious values of the time at which the standard was set or may be given content by a judge's own religious acculturation. These points are now discussed more fully.

\section{Objective standards in legal doctrines and their application to donors of strong religious faith}

Objective standards are not unusual in the law. The standard of the 'reasonable person' in the law of negligence is probably the most well known: whether a person is negligent is determined by comparing that person's conduct with how a reasonable person would have behaved in the same circumstances. Similarly, in legal doctrines regulating gift giving, the conduct of the donor of a gift is often measured against an objective standard of conduct. We have seen one objective standard already: the second requirement of equitable undue influence is that the gift is 'so large as not to be reasonably accounted for on the ground of friendship, relationship, charity, or other ordinary motives on which ordinary men act' ${ }^{27}$ Provided that a relationship of influence is found, the gift is measured against a societal norm of the 'ordinary motives of ordinary men'. Similarly, the case law that has interpreted family provision legislation requires that the donor of a testamentary gift has acted as a 'wise and just testator' 'determined by community standards of what is right and appropriate' in providing for his or her family and dependents. ${ }^{28}$ This also is an objective standard encapsulating a societal norm of the ideal testator. If the court finds that the donor did not meet this objective standard then it may order that family provision be paid by the donor's estate, to the diminution of the testamentary gifts that were in fact made by the donor.

The difficulty for donors motivated by strong religious faith is that their conduct may well be outside such normative standards; indeed, such donors may pride themselves on acting against such norms. A hypothetical (but not unrealistic) example is that of a Christian who chooses to give away all his or her property as an act of faith in God. Indeed, the equitable undue influence case of Allcard $v$ Skinner involved a similar scenario. Thus, a gift motivated by strong religious 
beliefs, particularly if those beliefs are outside the mainstream of religious beliefs in Australia, is likely to be more vulnerable to challenge on this ground. Professor Bradney has demonstrated in relation to English law that the application of objective standards in law generally is problematic for persons of strong religious conviction (whom Bradney calls 'obdurate believers'). ${ }^{29}$

Despite the difficulties that objective standards may cause for donors of strong religious faith, can it be argued that the application of objective standards in law is in fact a good thing? Surely one of the functions of law is to regulate behaviour so that it complies with societal norms? Furthermore, it could be said that the law is simply prioritising other values over the religious autonomy of the donor: protection from potential exploitation and recognition of the financial needs of the donor's family, for example. In other words, a compromise is being made. This may be so; nonetheless, it is important to be aware of the consequences of the discriminatory impact of objective standards upon gifts motivated by strong religious beliefs. First, such gifts are more vulnerable to challenge and thus security of receipt on the part of donees is correspondingly diminished. Secondly, in many instances it is not the donor who later seeks to overturn the gift, but the donor's family who would otherwise have stood to benefit. Thus, any discriminatory impact of objective standards that makes the relevant doctrines easier to comply with in relation to religiously motivated gifts may be exploited by persons other than the donor and this makes it important that such doctrines are scrutinised and critically evaluated. To give just one example, being aware that objective standards may impact unfairly on religiously motivated donors is relevant in considering how easily the presumption of equitable undue influence should arise. If the presumption is activated too readily then it is too easy to overturn an autonomous gift; if the presumption is too difficult to raise then there is a danger that gifts tainted by exploitative behaviour will stand.

\section{The content of objective standards}

Another danger with objective standards in their application to donors of strong religious faith concerns the content of such standards. The content of objective standards such as the 'ordinary motives of ordinary men' and 'the wise and just testator as determined by community standards of what is right and appropriate' is likely to reflect the dominant religious and cultural values of the society. ${ }^{30}$ This compounds the problems of a donor from a minority religious group who has strong religious beliefs. Not only are they unlikely to meet an objective standard based upon social norms, they are even less likely to meet a standard based on moderate Judeo-Christian or even secular world views (if we accept that these are the most likely influences upon the content of Australian legal standards). ${ }^{31}$ The problem is compounded because of our legal system's doctrine of precedent whereby judges must follow the decisions of higher courts; there 
may be a time lag in relation to the content of objective standards so that they do not keep apace with changes in societal norms. Thus, even though Australia is indisputably a multicultural society, this fact may take longer to infiltrate the content of objective standards in the law. Furthermore, judges may (consciously or unconsciously) rely upon their own religious acculturation in determining whether objective standards are met. For example, recently an Australian judge (apparently at the suggestion of legal counsel) applied Jesus' parable of the Forgiving Father in order to decide whether a testator had met the wise and just testator standard in family provision law. ${ }^{32}$ Thus, minority religious groups and/or religious groups new to Australia are disadvantaged if the content and application of objective standards in doctrines regulating gift giving encapsulate a moderate Judeo-Christian world view and all religious groups may be disadvantaged by objective standards that encapsulate a secular world view.

\section{Conclusion}

This brief review of the law concerning gifts motivated by strong religious beliefs shows that notwithstanding the professed reluctance of the courts to engage in a qualitative assessment of religious belief, the law does consider the donor's beliefs both directly and indirectly. Direct intervention in gift giving is justified on the basis of protection from exploitation: there is a strong concern regarding the power of spiritual influence with respect to inter vivos gifts motivated by religious faith but such concern lessens if the gift is testamentary. In addition, through family provision legislation, the religious motivations of a donor of testamentary gifts will be overridden if he or she has not provided for the financial needs of family members and dependents. Indirect engagement with a donor's religious beliefs occurs through the use of objective standards in the law. Objective standards based upon societal norms of gift giving are more difficult for 'obdurate believers' to comply with; furthermore, the content of such standards may embed a society's dominant religious values to the detriment of minority religions; the content of standards is also influenced by judicial religious acculturation.

What then, if anything, should be done about the law's negotiation of the sacred in this area? First, it is important simply to be aware of the issues outlined in this chapter so that the relevant case law and legislation can be evaluated in an informed manner, and so that reform may be advocated where necessary. It is impossible for the legal regulation of religiously motivated gifts to be entirely neutral in its treatment of the religious beliefs of the donor. Indeed, we may not want complete neutrality. Rather it is a matter of self awareness on the part of those who make and apply the law. It is important to consider competing values such as freedom of religion, autonomy of gift giving and expectations of close family and dependents of the donor for example, rather than to unthinkingly impose standards of acceptable gift giving that look value neutral but in fact 
discriminate against minority religious groups. The question of judicial acculturation is troublesome but also can be minimised by self awareness and education.

Two recent occurrences provide some encouragement that the Australian legal system and Australian law are on the right path in negotiating the sacred. The first concerns judicial discrimination against a minority religious group's beliefs. The NSW Court of Appeal recently overturned a finding of negligence in part because the lower court had improperly considered and criticised the defendants' religious motivations. ${ }^{33}$ Mason $\mathrm{P}$, speaking for the court in a strongly worded judgment, made it clear that judges are expected to overcome religious acculturation:

In the eye of the law it may not be unreasonable to hold categorically divergent opinions about certain matters of faith, morality or even good taste.

The second example concerns the law of charitable trusts. Historically, a bias against Roman Catholicism was apparent in the content and application of the legal requirements for a valid charitable trust. ${ }^{34}$ One such requirement was that the trust have a demonstrable 'public benefit'. ${ }^{35}$ Because of this the English courts refused to recognise trusts for the purposes of closed (predominantly Catholic) religious orders. It was said that a religious order which did not interact at all with the public could not be providing a public benefit through its activities and therefore a trust for the purposes of such an order would be invalid. ${ }^{36}$ Not surprisingly, the Irish High Court decided differently, and strongly endorsed the value of such religious activities within Ireland holding that, '[M]en's notions of public benefit will vary with the outlook of their age' ${ }^{37}$ The position in Australian law may have been clarified by the recent enactment of the Extension of Charitable Purpose Act 2004 (Cth). This Act provides that for the purposes of Commonwealth legislation an institution has a purpose with a public benefit if it is 'a closed or contemplative religious order that regularly undertakes prayerful intervention at the request of members of the public' ${ }^{38}$ While the legislative change only applies when Commonwealth legislation is in issue, undoubtedly it will affect the case law requirement of public benefit as well.

These two recent examples are encouraging as they show that it is possible to challenge judicial bias based upon religious acculturation, and that through political action there is the opportunity for those interested in the interaction of law and religious belief to take part in law reform. Religious institutions also have an important role in regulating and educating their members about such matters. 


\section{ENDNOTES}

1 Ridge, Pauline 2003, 'The Equitable Doctrine of Undue Influence Considered in the Context of Spiritual Influence and Religious Faith', University of New South Wales Law Journal, no. 26; 2003, 'Legal and Ethical Matters Relevant to the Receipt of Financial Benefits by Ministers of Religion and Churches', Griffith Law Review, no. 12; 2004, pp. 91-113. 'Testamentary Gifts Motivated by Religious Faith and Family Provision Legislation', Paper presented at the Centre for Cross-Cultural Research, Negotiating the Sacred conference, The Australian National University, Canberra, 31 May 2004.

2 Blake $v$ Associated Newspapers Ltd [2003] EWHC 1960 (Unreported, Gray J, 31 July 2003) [21]. See also, Hill, Mark 2001, 'Judicial Approaches to Religious Disputes' in Richard O'Dair and Andrew Lewis (eds), 2001, Law and Religion, Oxford, Oxford University Press,p. 409.

3 Scandrett $v$ Dowling (1992) 27 NSWLR 483.

4 Ogilvie, M. H. 1992, 'Church Property Disputes: Some Organizing Principles', University of Toronto Law Journal, no. 42, pp. 377, 392-393. Ogilvie criticises the Canadian courts for abdicating their role.

5 Church of the New Faith $v$ Commissioner for Pay Roll Tax (Vic) (1983) 154 CLR 120, 150.

6 Attorney-General for New South Wales v Grant (1976) 135 CLR 587.

7 Church of the New Faith $v$ Commissioner for Pay Roll Tax (Vic) (1983) 154 CLR 120.

8 Church of the New Faith $v$ Commissioner for Pay Roll Tax (Vic) (1983) 154 CLR 171 (Wilson and Deane JJ, citing United States $v$ Kuch (1968) 288 F Supp 439).

9 For example, Family Provision Act 1982 (NSW).

10 Allcard v Skinner (1887) LR 36 Ch D 145, 185 (Lindley LJ).

11 Johnson $v$ Buttress (1936) 56 CLR 113.

12 Allcard v Skinner (1887) LR 36 Ch D 145, 183 (Lindley LJ).

13 Huguenin v Baseley (1807) 14 Ves Jr 273, 288; 33 ER 526, 532 (Sir Samuel Romilly, during argument). These concerns were reiterated recently in Quek $v$ Beggs (1990) 5 BPR [97405].

14 See, for example, Nottidge $v$ Prince (1860) 2 Giff 246; 66 ER 103, Lyon $v$ Home (1868) LR 6 Eq 655; Morley v Loughnan [1893] 1 Ch 763; Chennells v Bruce (1939) 55 TLR 422.

15 See, Ridge, Pauline 2003, 'The Equitable Doctrine of Undue Influence Considered in the Context of Spiritual Influence and Religious Faith' University of New South Wales Law Journal, no. 26, 66.

16 Quek $v$ Beggs (1990) 5 BPR [97405]; Hartigan v International Society for Krishna Consciousness Inc [2002] NSWSC 810 (Unreported, Bryson J, 6 September 2002); McCulloch v Fern [2001] NSWSC 406 (Unreported, Palmer J, 28 May 2001). See also, Ridge, Pauline 2002, 'McCulloch v Fern', Journal of Contract Law, no. 18, 138.

17 Illuzzi $v$ Christian Outreach Centre (1997) Q ConvR pp. 54-490.

18 For example, Uniting Church in Australia, Code of Ethics and Ministry Practice, section 5.

19 For example, Hall v Hall (1868) LR 1 P \& D 481; Winter $v$ Crichton (1991) 23 NSWLR 116.

20 Parfitt $v$ Lawless (1872) LR 2 P \& D 462, 474 (Lord Penzance).

21 Barry v Butlin [1838] 2 Moo 480; 12 ER 1089; Tyrrell v Painton [1894] P 151; Nock v Austin (1918) 25 CLR 519.

22 (1892) 18 VLR 739.

23 Ridge, Pauline 2004, 'Equitable Undue Influence and Wills', Law Quarterly Review, no. 120, 617.

24 (1960) 104 CLR 394, 414.

25 [1967] VR 91.

26 Family Provision Act 1982 (NSW) section 7. See generally, Pauline Ridge, 'Testamentary Gifts Motivated by Religious Faith and Family Provision Legislation' (forthcoming article).

27 Allcard v Skinner (1887) LR 36 Ch D 145, 185 (Lindley LJ).

28 Bosch $v$ Perpetual Trustee Co [1938] AC 463; Permanent Trusteee Co Ltd v Fraser (1995) 36 NSWLR 24.

29 Bradney, Anthony 2000, 'Faced by Faith' in Peter Oliver, Douglas Scott Sionadh and Victor Tadros (eds), Faith in Law: Essays in Legal Theory, Oxford, Hart Publishing, p. 89.

30 See in relation to tort law, Calabresi, Guido 1985, Ideals, Beliefs, Attitudes and the Law, Syracuse, N.Y., Syracuse University Press.

31 See generally, Mason, Keith 1990, Constancy and Change: Moral and Religious Values in the Australian Legal System, Sydney, Federation Press. 
32 Hackett v Public Trustee (Unreported, ACT Supreme Court, Higgins J, 2 May 1997).

33 The Local Spiritual Assembly of the Baha'is of Parramatta Ltd v Haghighat (2004) Aust Torts Reports 81-729.

34 See Ricketts, C. E. F. 1990, 'An Anti-Roman Catholic Bias in the Law of Charity?' The Conveyancer and Property Lawyer, no. 34, pp. 34-44.

35 Gilmour $v$ Coats [1949] AC 426. See generally, Ford and Lee, 1983.

36 Gilmour $v$ Coats [1949] AC 426. See generally, Ford and Lee, 1983.

37 Maguire v Attorney General [1943] IR 238, 244 (Gavan Duffy J).

38 Section 5(1)(b). 